\title{
ANALYSIS OF CAUSES OF EARLY NEONATAL MORTALITY DURING COVID-19 PANDEMIC IN 2020 IN RUSSIA
}

\author{
Tumanova UN ${ }^{1}$, Shchegolev $\mathrm{Al}^{1,2}$, Chausov $\mathrm{AA}^{1}$, Shuvalova MP1 \\ ${ }^{1}$ Kulakov National Medical Research Center for Obstetrics, Gynecology and Perinatology, Moscow, Russia \\ 2 Pirogov Russian National Medical Research University, Moscow, Russia
}

\begin{abstract}
In March 2020, the World Health Organization declared a COVID-19 pandemic. The aim of this study was to compare the causes of and statistics on neonatal mortality in Russia in 2020 and 2019 using the Rosstat A-5 forms that aggregate data from perinatal death certificates. In 2020 , there was a $7.6 \%$ reduction in the absolute number of live births relative to 2019. In 2020, the overal early neonatal death rate (1.59\%) fell by $4.4 \%$ in comparison with 2019 (1.67\%). However neonatal mortality rates in the Southern and Far Eastern Federal Districts rose by $20.5 \%$ and $6.1 \%$, respectively. Respiratory diseases were the most common cause of early neonatal mortality across Russia (37.3\% and 40.2\% relative to the total number of neonatal deaths in 2019 and 2020 , respectively). Congenital sepsis accounted for $43.6 \%$ and $46.6 \%$ of early neonatal deaths from infectious diseases and for $7.3 \%$ and $7.9 \%$ of all early neonatal deaths reported in 2019 and 2020 , respectively. There was an increase in the proportion of respiratory diseases among neonates, including congenital pneumonia and other respiratory conditions, and infections, including congenital sepsis, which reflects the direct and indirect effects of SARS-CoV-2 infection on pregnant women and neonates.
\end{abstract}

Keywords: neonate, early neonatal mortality, cause of death, regional features, COVID-19

Author contribution: Tumanova UN — study design, Rosstat data analysis, literature search and analysis, manuscript preparation; Shchegolev Al — Rosstat data analysis and summarization, literature analysis, manuscript editing; Chausov AA — Rosstat data analysis, statistical analysis; Shuvalova MP — Rosstat data analysis, manuscript editing.

$\triangle$ Correspondence should be addressed: Alexandr I. Shchegolev

Oparina, 4, Moscow, 117997, Russia; ashegolev@oparina4.ru

Received: 15.09.2021 Accepted: 29.09.2021 Published online: 05.10.2021

DOI: $10.24075 /$ brsmu.2021.045

\section{АНАЛИЗ ПРИЧИН РАННЕЙ НЕОНАТАЛЬНОЙ СМЕРТНОСТИ В РОССИЙСКОЙ ФЕДЕРАЦИИ В 2020 Г. (ГОД ПАНДЕМИИ COVID-19)}

У. Н. Туманова' ${ }^{1}$ А. И. Щеголев ${ }^{1,2}$, А. А. Чаусов ${ }^{1}$, М. П. Шувалова

${ }^{1}$ Национальный медицинский исследовательский центр акушерства, гинекологии и перинатологии имени В. И. Кулакова, Москва, Россия

2 Российский национальный медицинский исследовательский университет имени Н. И. Пирогова, Москва, Россия

\begin{abstract}
В марте 2020 г. Всемирная организация здравоохранения объявила о пандемии COVID-19. Целью работы было провести сравнительный анализ причин и показателей ранней неонатальной смертности в Российской Федерации (РФ) в 2020 и 2019 г. с помощью статистических форм А-05 Росстата за 2019 и 2020 г., составленных на основании записей в медицинских свидетельствах о перинатальной смерти и относящихся к случаям ранней неонатальной смерти. В 2020 г. в РФ зарегистрировано уменьшение абсолютного числа живых новорожденных на 7,6\% по сравнению с данными 2019 г. Показатель ранней неонатальной смертности в 2020 г. (1,59\%) снизился на 4,4\% по сравнению с показателем 2019 г. (1,67\%о). Однако в Южном и Дальневосточном федеральных округах показатели ранней неонатальной смертности повысились на 20,5 и 6,1\% соответственно. В целом по РФ наиболее частой причиной ранней неонатальной смертности были заболевания, входящие в группу респираторных нарушений, составившие 37,3 и 40,2\% от общего числа умерших новорожденных в 2019 и 2020 г. соответственно. Доля врожденного сепсиса как первоначальной причины смерти составила 43,6 и 46,6\% в группе инсекционных заболеваний и 7,3 и 7,9\% от всех умерших новорожденных в 2019 и 2020 г. соответственно. Установлено увеличение доли заболеваний, входящих в группу респираторных нарушений, включая врожденную пневмонию и так называемые другие респираторные состояния, а также инфекций, в том числе врожденного сепсиса, что отражает негативное прямое и опосредованное влияние SARS-CoV-2-инфицирования у беременных и у новорожденных.
\end{abstract}

Ключевые слова: новорожденный, ранняя неонатальная смерть, причина смерти, региональные особенности, COVID-19

Вклад авторов: У. Н. Туманова - дизайн работы, анализ данных Росстата, поиск и анализ данных литературы, написание текста; А. И. Щеголев анализ и обобщение данных Росстата, анализ данных литературы, редактирование текста; А. А. Чаусов - анализ данных Росстата, статистическая обработка; М. П. Шувалова - анализ данных Росстата, редактирование текста.

$\triangle$ Для корреспонденции: Александр Иванович Щеголев ул. Опарина, д. 4, г. Москва, 117997, Россия; ashegolev@oparina4.ru Статья получена: 15.09.2021 Статья принята к печати: 29.09.2021 Опубликована онлайн: 05.10.2021 DOI: $10.24075 /$ vrgmu.2021.045

The first cases of the novel coronavirus infection caused by SARS-CoV-2 (severe acute respiratory syndrome, coronavirus-2) and later termed COVID-19 (coronavirus disease 2019) were reported in Wuhan, China, in December 2019 [1]. The virus was highly transmissible and rapidly spread across the globe. By March 11, 2020 there were over 100,000 confirmed COVID-19 cases worldwide, and $\mathrm{WHO}$ had to declare a pandemic [2].

Unfortunately, the implemented containment measures, the proposed treatments and the mass vaccination campaign have failed to stop the spread of the infection. Clinical presentations of COVID-19 vary from asymptomatic to severe infection and death. By March 2020, mortality from COVID-19 had reached
5-6\% in China and 15\% in other world's regions [3]. The elderly are the most affected by COVID-19; the prevalence of the severe disease is also the highest in this age group [4]. COVID-19 is detected in children and neonates less frequently, and pediatric outcomes are much better [5]. However, placental damage due to COVID-19 and SARS-CoV-2 infection in neonates may affect overall neonatal morbidity and mortality. In light of this, it may be important to analyze the rates and causes of neonatal mortality in 2020, the year of COVID-19 pandemic, and compare them to 2019.

The aim of this study was to compare the causes and rates of early neonatal mortality in Russia in 2020 and 2019. 
Table 1. The number of neonates who died in the early neonatal period in Russia in 2019 and 2020. The table shows absolute values and the percentage from the total number of early neonatal deaths in Russia

\begin{tabular}{|c|c|c|c|c|c|}
\hline Russia & Total & Female & Male & Urban & Rural \\
\hline 2019 & 2475 & $\begin{array}{c}1377 \\
(55,6)^{\star}\end{array}$ & $\begin{array}{c}1098 \\
(44,4)\end{array}$ & $\begin{array}{c}1855 \\
(74,9)^{\star \star}\end{array}$ & $\begin{array}{c}620 \\
(25,1)\end{array}$ \\
\hline 2020 & 2288 & $\begin{array}{l}1332^{*} \\
(58,2)\end{array}$ & $\begin{array}{c}956 \\
(41,8)\end{array}$ & $\begin{array}{c}1696 \\
(74,1)^{\star \star}\end{array}$ & $\begin{array}{c}592 \\
(25,9)\end{array}$ \\
\hline
\end{tabular}

Note: ${ }^{*}-p<0.01$ for comparison between male and female deaths, ${ }^{* *}-p<0.01$ for comparison between urban and rural areas.

\section{METHODS}

We analyzed A-05 statistical forms collected in 2019 and 2020. These forms are available from Rosstat (Russian Federal State Statistics Service) and aggregate data from perinatal death certificates. We chose those that reported early neonatal mortality. Since January 1, 2012, early neonatal death has been officially defined as the death of a neonate born at gestational week 22 or later with a body weight of $500 \mathrm{~g}$ or higher within $168 \mathrm{~h}$ after birth.

The primary causes of early neonatal death were arranged in 8 groups: birth trauma (group I); diseases of the respiratory system (group II); infectious diseases (group III); hemorrhagic and hematologic disorders (group IV); endocrine, metabolic and other disorders specific to the perinatal period (group V); congenital malformatins (group $\mathrm{VI}$ ); injuries and poisoning (group VII); other or unspecified causes (group VIII).

The early neonatal mortality rate was calculated as the number of neonates dying within $168 \mathrm{~h}$ after birth per 1,000 live births. Quantitative variables were compared using the chisquared test.

\section{RESULTS}

According to the data extracted from the obtained A-05 forms, there were 1,481, 074 live births in Russia in 2019; of them 2,475 neonates died within $168 \mathrm{~h}$ after birth (Table 1). In 2020, the absolute number of live births fell by $7.6 \%$ relative to the number of live births in 2019 , and the early neonatal mortality rate fell by $4.4 \%$ (1.59\% in 2020 vs $1.67 \%$ in 2019$)$.

This reflects the downward trend in early neonatal mortality observed in Russia in the past few years. So, for better accuracy of analysis, we decided to compare data accumulated in 2020 to the data from 2019. In 2012, when the current criteria of a birth (weight $\geq 500 \mathrm{~g}$, gestational week 22 or later) were introduced, there were 6,969 reports of neonatal deaths within $168 \mathrm{~h}$ after birth, with the early neonatal mortality rate of $3.66 \%$ [6]. To put that into perspective, there were 4,948 early neonatal deaths with the early neonatal mortality rate of $2.75 \%$ in 2010 when early neonatal death was still defined as the death of a neonate born at week 28 of gestation with a body weight of $1,000 \mathrm{~g}$ or higher within $168 \mathrm{~h}$ after birth [7]. So, the early neonatal mortality rate fell by $42.2 \%$ and $56.6 \%$ relative to the figures reported in 2010 and 2012, respectively.

From all neonatal deaths within $168 \mathrm{~h}$ after birth, male deaths made up 54.7\% in 2019 and 58.2\% in 2020 and female deaths amounted to $45.3 \%$ and $41.8 \%$, respectively. This means that in 2020 the proportion of early neonatal deaths among boys increased by $6.4 \%$ but dropped by $7.7 \%$ for girls. Most early neonatal deaths were reported in urban as compared to rural areas: $74.9 \%$ in 2019 and $74.1 \%$ in 2020 (Table 1).

The annual early neonatal death toll differed between Federal Districts (Table 2). In both years, the maximum number of neonatal deaths was reported in the Central FD (19.4\% and $19.0 \%$ of all early neonatal deaths in 2019 and 2020, respectively) and the Volga FD (19.4\% and $18.9 \%$, respectively). The lowest death toll was reported in the Far Eastern FD. Overall, there was a decline in neonatal deaths across Russia in 2020 in comparison with 2019, but the Southern and the Far Eastern FDs reported an increase by $17.2 \%$ and $5.4 \%$, respectively $(p=0.004)$. In 2020 , the early neonatal mortality rate in these regions rose by $20.5 \%$ and $6.1 \%$, respectively.

It is important to analyze the causes of neonatal mortality (Tables 3, 4). Overall, the majority of early neonatal deaths in

Table 2. The number of early neonatal deaths in the Federal Districts of Russia in 2019 and 2020. The table shows absolute values and the percentage from the total number of early neonatal deaths in Russia

\begin{tabular}{|c|c|c|c|c|}
\hline \multirow{2}{*}{ District } & \multicolumn{2}{|c|}{2019} & \multicolumn{2}{|c|}{2020} \\
\hline & $n(\%)$ & ENMR & $n(\%)$ & ENMR \\
\hline Russia, total & 2475 & 1,67 & 2288 & 1,59 \\
\hline Central & $\begin{array}{c}480 \\
(19,4)\end{array}$ & 1,31 & $\begin{array}{c}435 \\
(19,0)\end{array}$ & 1,22 \\
\hline Northwestern & $\begin{array}{l}216 \\
(8,7)\end{array}$ & 1,62 & $\begin{array}{l}167 \\
(7,3)\end{array}$ & 1,31 \\
\hline Southern & $\begin{array}{l}244 \\
(9,9)\end{array}$ & 1,51 & $\begin{array}{c}286 \\
(12,5)^{\star}\end{array}$ & 1,82 \\
\hline North Caucasian & $\begin{array}{c}343 \\
(13,9)\end{array}$ & 2,53 & $\begin{array}{c}315 \\
(13,8)\end{array}$ & 2,31 \\
\hline Volga & $\begin{array}{c}482 \\
(19,5)\end{array}$ & 1,72 & $\begin{array}{c}433 \\
(18,9)\end{array}$ & 1,61 \\
\hline Ural & $\begin{array}{l}215 \\
(8,7)\end{array}$ & 1,6 & $\begin{array}{l}188 \\
(8,2)\end{array}$ & 1,44 \\
\hline Siberian & $\begin{array}{c}347 \\
(14,0)\end{array}$ & 1,95 & $\begin{array}{c}308 \\
(13,5)\end{array}$ & 1,81 \\
\hline Far Eastern & $\begin{array}{l}148 \\
(6,0)\end{array}$ & 1,63 & $\begin{array}{l}156 \\
(6,8)\end{array}$ & 1,73 \\
\hline
\end{tabular}

Note: ENMR: early neonatal mortality rate; ${ }^{*}-p<0.05$ for comparison with 2019. 
Table 3. The primary causes of early neonatal mortality in different Federal Districts of Russia in 2019. The table shows absolute values and the percentage from the total number of early neonatal deaths in Russia/District

\begin{tabular}{|c|c|c|c|c|c|c|c|c|}
\hline \multirow{2}{*}{ District } & \multicolumn{8}{|c|}{ Primary causes of death } \\
\hline & I & II & III & IV & V & VI & VII & VIII \\
\hline Russia, total & $\begin{array}{c}17 \\
(0,7)\end{array}$ & $\begin{array}{c}924 \\
(37,3)\end{array}$ & $\begin{array}{c}413 \\
(16,7)\end{array}$ & $\begin{array}{c}412 \\
(16,6)\end{array}$ & $\begin{array}{l}213 \\
(8,6)\end{array}$ & $\begin{array}{c}434 \\
(17,5)\end{array}$ & $\begin{array}{c}16 \\
(0,6)\end{array}$ & $\begin{array}{c}46 \\
(1,9)\end{array}$ \\
\hline Central & $\begin{array}{c}2 \\
(0,4)\end{array}$ & $\begin{array}{c}121 \\
(25,2)\end{array}$ & $\begin{array}{c}56 \\
(11,7)\end{array}$ & $\begin{array}{c}84 \\
(17,5)\end{array}$ & $\begin{array}{c}69 \\
(14,4)\end{array}$ & $\begin{array}{c}138 \\
(28,8)\end{array}$ & 0 & $\begin{array}{c}10 \\
(2,8)\end{array}$ \\
\hline Northwestern & $\begin{array}{c}1 \\
(0,5)\end{array}$ & $\begin{array}{c}98 \\
(45,4)\end{array}$ & $\begin{array}{c}48 \\
(22,2)\end{array}$ & $\begin{array}{c}26 \\
(12,0)\end{array}$ & $\begin{array}{c}12 \\
(5,6)\end{array}$ & $\begin{array}{c}28 \\
(13,0)\end{array}$ & $\begin{array}{c}2 \\
(0,9)\end{array}$ & $\begin{array}{c}1 \\
(0,5)\end{array}$ \\
\hline Southern & $\begin{array}{c}3 \\
(1,2)\end{array}$ & $\begin{array}{c}102 \\
(41,8)\end{array}$ & $\begin{array}{c}47 \\
(19,3)\end{array}$ & $\begin{array}{c}44 \\
(18,0)\end{array}$ & $\begin{array}{c}13 \\
(5,3)\end{array}$ & $\begin{array}{c}27 \\
(11,1)\end{array}$ & $\begin{array}{c}1 \\
(0,4)\end{array}$ & $\begin{array}{c}7 \\
(2,9)\end{array}$ \\
\hline $\begin{array}{c}\text { North } \\
\text { Caucasian }\end{array}$ & 0 & $\begin{array}{c}148 \\
(43,1)\end{array}$ & $\begin{array}{c}50 \\
(14,6)\end{array}$ & $\begin{array}{c}51 \\
(14,9)\end{array}$ & $\begin{array}{c}34 \\
(9,9)\end{array}$ & $\begin{array}{c}59 \\
(17,2)\end{array}$ & 0 & $\begin{array}{c}1 \\
(0,3)\end{array}$ \\
\hline Volga & $\begin{array}{c}3 \\
(0,6)\end{array}$ & $\begin{array}{c}171 \\
(35,5)\end{array}$ & $\begin{array}{c}79 \\
(16,4)\end{array}$ & $\begin{array}{c}134 \\
(27,8)\end{array}$ & $\begin{array}{c}18 \\
(3,7)\end{array}$ & $\begin{array}{c}68 \\
(14,1)\end{array}$ & $\begin{array}{c}5 \\
(1,0)\end{array}$ & $\begin{array}{c}4 \\
(0,8)\end{array}$ \\
\hline Ural & $\begin{array}{c}1 \\
(0,5)\end{array}$ & $\begin{array}{c}75 \\
(34,9)\end{array}$ & $\begin{array}{c}53 \\
(24,7)\end{array}$ & $\begin{array}{c}24 \\
(11,2)\end{array}$ & $\begin{array}{c}9 \\
(4,2)\end{array}$ & $\begin{array}{c}44 \\
(20,5)\end{array}$ & $\begin{array}{c}5 \\
(2,3)\end{array}$ & $\begin{array}{c}4 \\
(1,9)\end{array}$ \\
\hline Siberian & $\begin{array}{c}5 \\
(1,4)\end{array}$ & $\begin{array}{c}137 \\
(39,5)\end{array}$ & $\begin{array}{c}66 \\
(19,0)\end{array}$ & $\begin{array}{l}25 \\
(7,2)\end{array}$ & $\begin{array}{c}42 \\
(12,1)\end{array}$ & $\begin{array}{c}55 \\
(15,8)\end{array}$ & $\begin{array}{c}3 \\
(0,9)\end{array}$ & $\begin{array}{c}14 \\
(4,0)\end{array}$ \\
\hline Far Eastern & $\begin{array}{c}2 \\
(1,4)\end{array}$ & $\begin{array}{c}72 \\
(48,6)\end{array}$ & $\begin{array}{c}14 \\
(9,5)\end{array}$ & $\begin{array}{c}24 \\
(16,2)\end{array}$ & $\begin{array}{c}16 \\
(10,8)\end{array}$ & $\begin{array}{c}15 \\
(10,1)\end{array}$ & 0 & $\begin{array}{c}5 \\
(3,4)\end{array}$ \\
\hline
\end{tabular}

Russia throughout the analyzed period were caused by respiratory system disorders (group II). In 2019, such conditions accounted for $37.3 \%$ of all early neonatal deaths. In 2020 , the contribution of respiratory conditions to the total neonatal death toll was $40.2 \%$, i.e. it increased by $7.8 \%(p=0.042)$ in comparison with 2019. Most of such deaths occurred due to hyaline membrane disease $(16.6 \%$ and $15.3 \%$ of all early neonatal deaths in 2019 and 2020, respectively). A high proportion of deaths was attributed to birth asphyxia and congenital pneumonia. In 2019, these 2 conditions killed 212 and 200 newborns, or $8.6 \%$ and $8.1 \%$, respectively. In 2020 , deaths from birth asphyxia fell by 9.5\% but their proportion in the total number of early neonatal deaths lowered by only $2.0 \%$. Congenital pneumonia was more prevalent in 2020 (by 17.0\%; $p=0.011$ ) and its contribution to the early neonatal death toll increased by $26.6 \%$. There was a surge in the number (by 43.4\%; $p=0.003$ ) and proportion (54.8\%) of respiratory conditions referred to as other respiratory conditions originating in the perinatal period, including lung immaturity, atelectasis, aspiration syndrome, etc.
Congenital malformations (group VI) ranked second among the primary causes of early neonatal mortality in 2019. They caused death of 434 newborns $(17.5 \%$ of all early neonatal deaths). In 2020, congenital malformations ranked fourth and were diagnosed in 354 (15.5\%) cases.

The most common type of congenital malformation was a multiple congenital anomaly. Congenital malformations were the primary cause of death in 196 cases $(7.9 \%$ of all early neonatal deaths) in 2019 and in 190 (8.3\%) cases in 2020. The second most prevalent congenital malformation was congenital malformation of the heart that killed 123 neonates (28.3\% of all congenital anomalies in group $\mathrm{VI}$ and $5.0 \%$ of total neonatal deaths) in 2019. In 2020, congenital malformations of the heart were much less frequent and caused 87 neonatal deaths (24.6\% of all congenital malformations and $3.8 \%$ of the total number of neonatal deaths).

Infectious diseases (group III) were the third most common cause of death in 2019 and the second most common cause of death in $2020(16.7 \%$, or 413 cases and $17.0 \%$, or 388

Table 4. The primary causes of early neonatal mortality in different Federal Districts of Russia in 2020. The table shows absolute values and the percentage from the total number of early neonatal deaths in Russia/District

\begin{tabular}{|c|c|c|c|c|c|c|c|c|}
\hline \multirow{2}{*}{ District } & \multicolumn{8}{|c|}{ Primary causes of death } \\
\hline & I & ॥ & III & IV & $\mathrm{V}$ & VI & VII & VIII \\
\hline Russia, total & $\begin{array}{c}19 \\
(0,8)\end{array}$ & $\begin{array}{c}920 \\
(40,2)\end{array}$ & $\begin{array}{c}388 \\
(17,0)\end{array}$ & $\begin{array}{c}359 \\
(15,7)\end{array}$ & $\begin{array}{l}198 \\
(8,7)\end{array}$ & $\begin{array}{l}354 \\
(15,5)\end{array}$ & $\begin{array}{l}20 \\
(0,9)\end{array}$ & $\begin{array}{l}30 \\
(1,3)\end{array}$ \\
\hline Central & $\begin{array}{c}3 \\
(0,7)\end{array}$ & $\begin{array}{c}117 \\
(26,9)\end{array}$ & $\begin{array}{c}74 \\
(17,0)\end{array}$ & $\begin{array}{c}80 \\
(18,4)\end{array}$ & $\begin{array}{c}54 \\
(12,4)\end{array}$ & $\begin{array}{c}92 \\
(21,1)\end{array}$ & $\begin{array}{c}7 \\
(1,6)\end{array}$ & $\begin{array}{c}8 \\
(1,8)\end{array}$ \\
\hline Northwestern & $\begin{array}{c}1 \\
(0,6)\end{array}$ & $\begin{array}{c}73 \\
(43,7)\end{array}$ & $\begin{array}{c}35 \\
(21,0)\end{array}$ & $\begin{array}{c}20 \\
(12,0)\end{array}$ & $\begin{array}{c}9 \\
(5,4)\end{array}$ & $\begin{array}{c}29 \\
(17,4)\end{array}$ & 0 & 0 \\
\hline Southern & $\begin{array}{c}2 \\
(0,7)\end{array}$ & $\begin{array}{l}150 \\
(52,4)\end{array}$ & $\begin{array}{c}30 \\
(10,5)\end{array}$ & $\begin{array}{c}51 \\
(17,8)\end{array}$ & $\begin{array}{c}7 \\
(2,4)\end{array}$ & $\begin{array}{c}39 \\
(13,6)\end{array}$ & $\begin{array}{c}2 \\
(0,7)\end{array}$ & $\begin{array}{c}5 \\
(1,7)\end{array}$ \\
\hline $\begin{array}{c}\text { North } \\
\text { Caucasian }\end{array}$ & $\begin{array}{c}4 \\
(1,3)\end{array}$ & $\begin{array}{c}120 \\
(38,1)\end{array}$ & $\begin{array}{c}57 \\
(18,1)\end{array}$ & $\begin{array}{c}34 \\
(10,8)\end{array}$ & $\begin{array}{c}4 \\
(14,3)\end{array}$ & $\begin{array}{c}51 \\
(16,2)\end{array}$ & $\begin{array}{c}2 \\
(0,6)\end{array}$ & $\begin{array}{c}2 \\
(0,6)\end{array}$ \\
\hline Volga & $\begin{array}{c}1 \\
(0,2)\end{array}$ & $\begin{array}{c}181 \\
(41,8)\end{array}$ & $\begin{array}{c}71 \\
(16,4)\end{array}$ & $\begin{array}{c}95 \\
(21,9)\end{array}$ & $\begin{array}{c}25 \\
(5,8)\end{array}$ & $\begin{array}{c}53 \\
(12,2)\end{array}$ & $\begin{array}{c}3 \\
(0,7)\end{array}$ & $\begin{array}{c}4 \\
(0,9)\end{array}$ \\
\hline Ural & 0 & $\begin{array}{c}76 \\
(40,4)\end{array}$ & $\begin{array}{c}49 \\
(26,1)\end{array}$ & $\begin{array}{l}17 \\
(9,0)\end{array}$ & $\begin{array}{c}13 \\
(6,9)\end{array}$ & $\begin{array}{c}26 \\
(13,8)\end{array}$ & $\begin{array}{c}4 \\
(2,1)\end{array}$ & $\begin{array}{c}3 \\
(1,6)\end{array}$ \\
\hline Siberian & $\begin{array}{c}6 \\
(1,9)\end{array}$ & $\begin{array}{c}124 \\
(40,3)\end{array}$ & $\begin{array}{c}60 \\
(19,5)\end{array}$ & $\begin{array}{c}41 \\
(13,3)\end{array}$ & $\begin{array}{l}27 \\
(8,8)\end{array}$ & $\begin{array}{c}44 \\
(14,3)\end{array}$ & $\begin{array}{c}1 \\
(0,3)\end{array}$ & $\begin{array}{c}5 \\
(1,6)\end{array}$ \\
\hline Far Eastern & $\begin{array}{c}2 \\
(1,3)\end{array}$ & $\begin{array}{c}79 \\
(50,6)\end{array}$ & $\begin{array}{c}12 \\
(7,7)\end{array}$ & $\begin{array}{c}21 \\
(13,5)\end{array}$ & $\begin{array}{c}18 \\
(11,5)\end{array}$ & $\begin{array}{c}20 \\
(12,8)\end{array}$ & $\begin{array}{c}1 \\
(0,6)\end{array}$ & $\begin{array}{c}3 \\
(1,9)\end{array}$ \\
\hline
\end{tabular}


cases, respectively). Congenital sepsis was the primary cause of death in 180 and 181 cases in 2019 and 2020, respectively. It accounted for $43.6 \%$ and $46.6 \%$ of infectious diseases in this group and made up $7.3 \%$ and $7.9 \%$ of all neonatal deaths in 2019 and 2020, respectively. Other infections specific to the perinatal period caused death of 232 and 205 neonates in 2019 and 2020, respectively; these infections made up $56.2 \%$ and $52.8 \%$ of all infectious diseases in group III, receptively, and caused $9.4 \%$ and $9.0 \%$ of all neonatal deaths, respectively.

Hemorrhagic and hematologic disorders (group IV) were the primary cause of neonatal mortality in 412 cases $(16.6 \%$ of all early neonatal deaths) in 2019 and the fourth most common cause of neonatal death overall. In 2020, the absolute (359) and relative (15.7\%) numbers of early neonatal deaths associated with this group of conditions were lower but the disorders still ranked third among the most common causes of early neonatal mortality. The total number of endocrine, metabolic and other disorders specific to the perinatal period (group V) decreased from 213 in 2019 to 198 in 2020 but their contribution to the total neonatal death toll increased from $8.6 \%$ to $8.7 \%$. It should be noted that there were fewer perinatal deaths due to unspecified causes in 2020 than in 2019 (42, or $1.7 \%$ of all neonatal deaths vs 27 , or $1.2 \%$ of all neonatal deaths).

The incidence of the described primary conditions in neonates differed between the Federal Districts in both 2019 and 2020 (Tables 3 and 4). The incidence of respiratory system disorders (group II) as the primary condition varied from 25.2\% to $48.6 \%$ in 2019 and from $26.9 \%$ to $52.4 \%$ in 2020 . These conditions were the least frequent primary condition in the Central FD (25.2\% and $26.9 \%$ of all early neonatal deaths, respectively, in 2019 and 2020) and the most frequent cause of early neonatal death in the Far Eastern FD (45.4\%) in 2019 and in the Southern FD (52.4\%) in 2020. Notably, there was a rise in the total number of neonates who died of respiratory system diseases in 2020 in comparison with 2019: by $47.1 \%$ and $9.7 \%$ $(p<0.01)$ in the Southern and Far Eastern FDs, respectively.

The greatest contribution of infectious diseases (group III) to early neonatal mortality in both years was observed in the Ural FD (24.7\% and 26.1\% in 2019 and 2020, respectively). The Central and North Caucasian FDs reported an increase in neonatal deaths caused by infectious diseases in 2020, as compared to 2019 (by $32.1 \%$ and 14\%, respectively; $p<0.04$ ). At the same time, neonatal deaths plunged by $36.2 \%$ and $27.1 \%$ $(p<0.01)$ in the Southern and Northwestern FDs, respectively.

The contribution of hemorrhagic and hematologic disorders constituting group IV to the causes of early neonatal mortality varied from 7.2\% (Siberian FD) to 27.8\% (Volga FD) in 2019 and from $9.0 \%$ (Ural FD) to $21.9 \%$ (Volga FD) in 2020. A rise in the number of early neonatal deaths caused by group IV diseases in 2020 as compared to 2019 occurred in the Siberian FD (by $64 \% ; p=0.022$ ) and Southern FD (by 15.9\%). In the North Caucasian and Volga FDs, early neonatal deaths fell by $33.3 \%$ and $31.7 \% \%$, respectively ( $p=0.042$ ).

The contribution of congenital malformations (group VI) varied from 10.1\% (in the Far Eastern FD) to 28.8\% (Central FD) in 2019 and from $12.2 \%$ (Volga FD) TO 21.1\% (Central FD) in 2020. An increase in the number of neonatal deaths caused by congenital malformations was reported in the Southern FD (by 44.4\%) and Far Eastern FD (by 33.3\%) in 2020 in comparison with 2019; a decline was observed in the Ural FD (by 40.1\%) and the Central FD (by 33.3\%; $p=0.013$ ).

The analysis of Rosstat data on early neonatal deaths in 2019 and 2020 revealed their decline in absolute and relative numbers. Besides, there were some changes in the structure of neonatal mortality causes and an increase in the number of neonatal deaths in a few FDs. Naturally, the contribution of SARS-CoV-2 to neonatal mortality has to be analyzed.

\section{DISCUSSION}

According to $\mathrm{WHO}$ recommendations and guidelines developed in Russia [8], all deaths associated with COVID-19 are broken down in 2 groups:

- COVID-19 as a primary cause of death;

- COVID-19 as another cause of death, significantly aggravating the primary condition or promoting its complications.

WHO has introduced additional codes to ICD to identify diseases and conditions that develop in the setting of COVID-19, for example: U07.1 (COVID-19, virus identified) and U07.2 (COVID-19, virus not identified). These codes are specified in neonatal death certificates and used in statistical analysis by Rosstat. Again, the primary causes of early neonatal death are classified according to Chapters XVI (Certain conditions originating in the perinatal period; P00-P96) and XVII (Congenital malformations, deformations and chromosomal abnormalities; Q00-Q99) of ICD-10. In Rosstat A-05 forms, the primary causes of neonatal death are reported as groups of diseases. Chapter XXII of ICD-10 (Codes for special purposes; U00-U85), which includes U07 (COVID-19), is reported as part of the class "Other causes of perinatal death". Therefore, it is impossible to extract the exact number of neonates who died from COVID-19 from Rosstat forms due to the absence of such data.

According to other reports of Rosstat, there were only 3 cases of other causes of perinatal death in 2020: in the Central, Southern and North Caucasian FDs. In 2019, a total of 4 such cases were reported: 2 in the Southern FD, one in the Volga FD and the other one in the Far Eastern FD. Even if all of these deaths were associated with COVID-19, which is highly unlikely, they accounted for only $0.17 \%$ of total early neonatal deaths in 2020. Therefore, as a primary condition COVID-19 did not increase early neonatal mortality.

At the same time, any comorbidity to a greater or lesser extent aggravates the course of a disease. In order to identify the primary cause of death and thanatogenesis components, the primary disease, the underlying condition and the cooccurring disease should be identified. The pathogenesis and thanatogenesis of COVID-19 are still not fully clear, so it would be logical to provide literature data on the neonatal incidence of COVID-19, its clinical manifestations and autopsy findings.

There are reports of SARS-CoV-2 infection in neonates. Transmission of the virus may occur in the uterus, at birth through exposure to maternal blood and/or uterine discharge or postpartum $[9,10]$. Intrauterine transplacental transmission has been reported not only in single case studies but also in systematic reviews. $\mathrm{WHO}$ has proposed a classification for vertical SARS-CoV-2 transmission. It allows comparing data generated by different studies and assessing clinical outcomes in neonates born to infected mothers [11].

SARS-CoV-2 was detected in $14.2 \%$ of pregnant women in Spain [12] and 16-20\% of pregnant women in New-York, USA [13]. As of July 1, 2020, there were 4,855 cases of COVID-19 among pregnant, parturient and postparturient females. By January 2021, their number had increased to 30,609.

Some researchers think that neonates are at risk for SARSCov-2 during vaginal unmedicated or minimally medicated delivery [14] because SARS-CoV-2 RNA was detected in maternal uterine swabs [15]. This is why Caesarean section was recommended to pregnant women infected with SARS-CoV-2 in the early days of the pandemic. At present, 
Caesarean sections are indicated based on the general health of the pregnant woman and the fetus but not on the presence of COVID-19 infection.

The systematic analysis of publications on 176 SARS-CoV-2infected neonates has established that intrauterine SARSCoV-2 infection occurred in only 30\% of cases; $70 \%$ of the neonates contracted the infection after birth from an infected individual [16]. This means that most transmissions occur through direct contact with infected individuals, including the mother, medical staff, family, and through contact with infected surfaces, especially steel and plastic, where the virus persists the longest [17].

The incidence of COVID-19 in neonates is much lower than in adults. However, to stabilize the condition of a neonate born to the infected mother, intensive care may be needed [18], which suggests the negative role of the infection. According to the most informative systematic review which included data on 176 SARS-CoV-2-infected neonates, only 97 (55.1\%) were symptomatic [16]. Of them, 52.5\% (51) had respiratory disorders, $44.3 \%$ (43) had fever, 36.0\% (35) had gastrointestinal disorders, $18.6 \%$ (18) had neurological conditions, 10.3\% (10) had cardiovascular disorders, and 9.2\% (9) had hypothermia, conjunctivitis or skin rashes.

Common clinical symptoms of COVID-19 in neonates include fever, nausea, diarrhea, hypotension, tachycardia, hypoglycemia, hypothermia, meconium aspiration, respiratory distress syndrome, hypoxic ischemic encephalopathy, and congenital malformations: atrial septal defects, patent foramen ovale, hemodynamically significant patent ductus arteriosus, and tetralogy of Fallot [19]. At the same time, a multicenter study conducted in Spain reports no difference in the incidence of congenital malformations of the fetus in pregnant women infected with SARS-CoV-2 vs healthy pregnant women [20].

Most researchers indicate a higher frequency of premature labor [21, 22] and fetal distress among women infected with COVID-19 [23, 24], which again suggests the detrimental effect of COVID-19 on neonatal health. For example, the frequency of premature labor among pregnant women infected with SARSCoV-2 was $11.4 \%$ vs $7.2 \%$ among healthy females $(p=0.054)$, and fetal distress was observed in $14 \%$ vs $9.1 \%$ of cases, respectively ( $p=0.036$ ) [20]. The proportion of prematurely born neonates with severe disorders was higher among pregnant women with COVID-19 than among healthy females: $9.6 \%$ vs $1 \%(p=0.006)[24]$

Some authors think that fetal distress is conditioned by poor blood oxygenation and systemic inflammation in the mother [24]. Morphological and functional defects of the placenta also play a role in intrauterine growth restriction. The overwhelming majority of researchers report that women with SARS-CoV-2-have placental damage manifesting as impaired blood flow between the maternal and fetal compartments and inflammation [25, 26]. Our earlier morphometric and immunohistochemical study conducted in pregnant women with COVID-19 has revealed increased numbers of syncytial knots, reduced vascularization and elevated VEGF expression in the villi indicating development of preplacental and placental hypoxia [27, 28]. Importantly, placental damage can lead to both intrauterine and early neonatal death. According to ICD-10, placental damage cannot be interpreted as the primary cause of death but should be viewed as a condition that promotes death. Rosstat data reveals that placental damage led to early neonatal death in $17.2 \%$ of cases in 2010 [7], and in $22.2 \%$ of cases in 2016 [6].

Although COVID-19 is clinically manifested in neonates, the outcomes are mostly positive in comparison with the outcomes in adult and elderly patients. According to the Italian National Institute of Health, mortality from COVID-19 among children aged 0-9 years was $0.01 \%$ as of March 29, 2021 [29]. A systematic review of 24 publications (9 case series and 15 individual cases) on the effects of COVID-19 on pregnant women, fetuses and neonates reported only 4 intrauterine deaths, including a pair of twins, and 3 neonatal deaths, including a pair of twins, caused by COVID-19 [30]. Another analysis of literature published before June 3, 2020 comprised data on 920 neonates born to SARS-CoV-2infected women, revealing only 2 (1.3\%) neonatal deaths [31] caused by pneumonia; in both cases tests for SARS-CoV-2 were negative. Two more neonates developed neonatal sepsis, of them one had septic shock. Both received treatment and were discharged in a satisfactory condition.

However, there was a case of neonatal death from septic shock $2 \mathrm{~h}$ after birth to the SARS-CoV-2-infected mother [32]. There was another report of death of a prematurely born neonate who died from refractory shock, multiple organ failure and disseminated intravascular coagulation 9 days after birth [33].

Recently, the World Association of Perinatal Medicine working group reported the results of an extensive multicenter multinational retrospective cohort study which included women with singlet pregnancy and confirmed SARS-CoV-2 infection and was conducted at 72 centers in 22 countries across Europe, Latin America, Asia Australia and USA from February 1 to April 30 [34]. According to the report, there were 5 / 251 (2.0\%) neonatal deaths: 3 babies were born prematurely, 2 died from sepsis. Notably the nasopharyngeal swab of $1(0.4 \%)$ of 251 neonates born alive tested positive for SARS-CoV-2. This partly explains the relatively low rate of neonatal mortality due to COVID-19 in general and in Russia in particular.

\section{CONCLUSIONS}

According to Rosstat, the absolute number of neonatal deaths within $168 \mathrm{~h}$ after birth and the early neonatal mortality rate fell in 2020 (the year of COVID-19). The A-05 form of Rosstat does not contain information on neonatal mortality from COVID-19 for the year 2020. The analysis of Rosstat data has revealed an increase in rate of respiratory system disorders, including congenital pneumonia and the so called other respiratory conditions, and infections, including congenital sepsis, which, in our opinion, reflects the immediate and indirect impacts of SARS-CoV-2 infection and COVID-19 in pregnant women and SARS-CoV-2 infection in neonates. To better understand the role of COVID-19 in early neonatal mortality, statistics on the primary cause of death and pre-existing conditions should be collected. There is also the need for the clinical and pathomorphological analysis of each neonatal death followed by systematization of the obtained data. 
1. Zhu N, Zhang D, Wang W, Wang W, Li X, Yang B, et al. A novel coronavirus from patients with pneumonia in China. 2019. N Engl J Med. 2020; 382 (8): 727-33.

2. Coronavirus Disease (COVID-19) Pandemic. https://www.who. int/emergencies/diseases/novel-coronavirus-2019.

3. Baud D, Qi X, Nielsen-Saines K, Musso D, Pomar L, Favre G, et al. Real estimates of mortality following COVID-19 infection. Lancet Infect Dis. 2020; 20 (7): 773.

4. Li J, Huang DQ, Zou B, Yang H, Hui WZ, Rui F, et al. Epidemiology of COVID-19: A systematic review and meta-analysis of clinical characteristics, risk factors, and outcomes. J Med Virol. 2021; 93 (3): 1449-58.

5. Liguoro I, Pilotto C, Bonanni M, Ferrari ME, Pusiol A, Nocerino A, et al. SARS-COV-2 infection in children and newborns: A systematic review. Eur J Pediatr. 2020; 179 (7): 1029-46.

6. Tumanova UN, Shuvalova MP, Shchegolev Al. Horioamnionit i rannjaja neonatal'naja smertnost' (po dannym Rosstata $v$ 20122016 godah). Mezhdunarodnyj zhurnal prikladnyh i fundamental'nyh issledovanij. 2018; (8): 49-53. Russian.

7. Shchegolev Al, Pavlov KA, Dubova EA., Frolova O. G. Rannjaja neonatal'naja smertnost' v Rossijskoj Federacii v 2010 g. Arhiv patologii. 2013; (4): 15-19. Russian.

8. Metodicheskie rekomendacii po kodirovaniju i vyboru osnovnogo sostojanija $v$ statistike zabolevaemosti i pervonachal'noj prichiny v statistike smertnosti, svjazannyh s COVID-19. 2020, 24 s. Dostupno po ssylke: https://static-1.rosminzdrav.ru/system/ attachments/attaches/000/050/527/original/27052020_MR_ STAT_1.pdf. Russian.

9. Schwartz DA. An analysis of 38 pregnant women With COVID-19, their newborn infants, and maternal-fetal transmission of SARSCoV-2: Maternal coronavirus infections and pregnancy outcomes. Arch Pathol Lab Med. 2020; 144 (7): 799-805.

10. Neef V, Buxmann H, Rabenau HF, Zacharowski K, Raimann FJ. Characterization of neonates born to mothers with SARS-CoV-2 infection: Review and meta-analysis. Pediatr Neonatol. 2021; 62 (1): 11-20.

11. WHO COVID-19 LENS (Living Evidence Synthesis) Working Group. Definition and categorization of the timing of motherto-child transmission of SARS-CoV-2. Available from: www. who.int/publications/i/item/WHO-2019-nCoV-mother-tochildtransmission-2021.1.

12. Garcia-Basteiro AL, Moncunill G, Tortajada M, Vidal M, Guinovart C Jiménez A, et al. Seroprevalence of antibodies against SARSCoV-2 among health care workers in a large Spanish reference hospital. Nat Commun. 2020; 11 (1): 3500.

13. Sutton D, Fuchs K, D'Alton M, Goffman D. Universal screening for SARS-CoV-2 in women admitted for delivery. $N$ Engl $J$ Med. 2020; 382 (22): 2163-4.

14. Ferrazzi E, Frigerio L, Savasi V, Vergani P., Prefumo F, Barresi S, et al. Vaginal delivery in SARS-CoV-2-infected pregnant women in Northern Italy: A retrospective analysis. BJOG. 2020; 127 (9): 1116-21.

15. Vivanti AJ, Vauloup-Fellous C, Prevot S, Zupan V, Suffee C, Do Cao J, et al. Transplacental transmission of SARS-CoV-2 infection. Nat Commun. 2020; 11 (1): 3572.

16. Raschetti R, Vivanti AJ, Vauloup-Fellous C, Loi B, Benachi A, De Luca D. Synthesis and systematic review of reported neonatal SARS-CoV-2 infections. Nat Commun. 2020; 11 (1): 5164.

17. Shchegolev Al, Tumanova UN. Persistence of SARS-COV-2 in deceased patients and safe handling of infected bodies. Bulletin of RSMU. 2021; (3): 5-11.

18. Degtyarev DN. Mozhno li rassmatrivat' virus SARS-COV-2 v kachestve vozbuditelja TORCH-infekcij u novorozhdennyh? Neonatologija: novosti, mnenija, obuchenie. 2021; (1): 5-7. Russian.

19. LiX, Sun L, Tao L. Updates in neonatal coronavirus disease 2019: What can we learn from detailed case reports? (Review). Mol Med Rep. 2021; 23 (5): 351.

20. Crovetto F, Crispi F, Llurba E, Pascal R, Larroya M, Trilla C, et al. Impact of SARS-CoV-2 infection on pregnancy outcomes: A population-based study. Clin Infect Dis. 2021: ciab104.

21. Yan J, Guo J, Fan C, Juan J, Yu X, Li J, et al. Coronavirus disease 2019 in pregnant women: a report based on 116 cases. Am J Obstet Gynecol. 2020; 223 (111): e1-14.

22. Knight M, Bunch K, Vousden N, Morris E, Simpson N, Gale C, et al. UK obstetric surveillance system SARSCoV-2 infection in Pregnancy Collaborative Group. Characteristics and outcomes of pregnant women admitted to hospital with confirmed SARSCoV-2 infection in UK: national population based cohort study. BMJ. 2020; 369: m2107.

23. Lee DH, Lee J, Kim E, Woo L, Park HY, An J. Emergency cesarean section performed in a patient with confirmed severe acute respiratory syndrome coronavirus-2 - a case report. Korean J Anesthesiol. 2020; 73 (4): 347-51.

24. Gracia-Perez-Bonfils A, Martinez-Perez O, Lurba E, Chandraharan E. Fetal heart rate changes on the cardiotocograph trace secondary to maternal COVID-19 infection. Eur J Obstet Gynecol Reprod Biol. 2020; 252: 286-93.

25. Oltean I, Tran J, Lawrence S, Ruschkowski BA, Zeng N, Bardwell C, et al. Impact of SARS-CoV-2 on the clinical outcomes and placental pathology of pregnant women and their infants: A systematic review. Heliyon. 2021; 7 (3): e06393.

26. Shchegolev Al, Tumanova UN, Serov VN. Porazhenija placenty u beremennyh s SARS-CoV-2-infekciej. Akusherstvo i ginekologija. 2020: (12): 44-52. Russian.

27. Shchegolev AI, Kulikova GV, Tumanova UN, Shmakov RG, Sukhikh GT. Morfometricheskaja harakteristika vorsin placenty rozhenic s COVID-19. Bjulleten' jeksperimental'noj biologii mediciny. 2021; 172 (7): 102-7. Russian.

28. Shchegolev Al, Kulikova GV, Lyapin VM, Shmakov RG, Sukhikh GT. The number of syncytial knots and vegf expres-sion in placental villi in parturient woman with COVID-19 depends on the disease severity. Bull Exp Biol Med. 2021; 171 (3): 399-403.

29. Italian National Institute of Health. COVID-19: National Update 24 March 2021 (Italian Version). Available from: www.epicentro.iss. it/coronavirus/bollettino/Bollettino-sorveglianza-integrata-COVID19 24-marzo-2021.pdf.

30. Juan J, Gil MM, Rong Z, Zhang Y, Yang H, Poon LC. Effect of coronavirus disease 2019 (COVID-19) on maternal, perinatal and neonatal outcome: systematic review. Ultrasound Obstet Gynecol. 2020; 56 (1): 15-27.

31. Bellos I, Pandita A, Panza R. Maternal and perinatal outcomes in pregnant women infected by SARS-CoV-2: A meta-analysis. Eur J Obstet Gynecol Reprod Biol. 2021; 256: 194-204.

32. Li J, Wang $Y$, Zeng $Y$, Song $T$, Pan $X$, Jia $M$, et al. Critically ill pregnant patient with COVID-19 and neonatal death within two hours of birth. Int J Gynaecol Obstet. 2020; 150 (1): 126-128.

33. Zhu H, Wang L, Fang C, Peng S, Zhang L, Chang G, et al. Clinical analysis of 10 neonates born to mothers with 2019-nCoV pneumonia. Transl Pediatr. 2020; 9: 51-60.

34. WAPM (World Association of Perinatal Medicine) Working Group on COVID-19. Maternal and perinatal outcomes of pregnant women with SARS-CoV-2 infection. Ultrasound Obstet Gynecol. 2021; 57 (2): 232-41.

\section{Литература}

1. Zhu N, Zhang D, Wang W, Wang W, Li X, Yang B, et al. A nove coronavirus from patients with pneumonia in China. 2019. N Eng J Med. 2020; 382 (8): 727-33.

2. Coronavirus Disease (COVID-19) Pandemic. https://www.who. int/emergencies/diseases/novel-coronavirus-2019.

3. Baud D, Qi X, Nielsen-Saines K, Musso D, Pomar L, Favre G, et al. Real estimates of mortality following COVID-19 infection. Lancet Infect Dis. 2020; 20 (7): 773.

4. Li J, Huang DQ, Zou B, Yang H, Hui WZ, Rui F, et al. Epidemiology of COVID-19: A systematic review and meta-analysis of clinical 
characteristics, risk factors, and outcomes. J Med Virol. 2021; 93 (3): $1449-58$

5. Liguoro I, Pilotto C, Bonanni M, Ferrari ME, Pusiol A, Nocerino A, et al. SARS-COV-2 infection in children and newborns: A systematic review. Eur J Pediatr. 2020; 179 (7): 1029-46.

6. Туманова У. Н., Шувалова М. П., Щеголев А. И. Хориоамнионит и ранняя неонатальная смертность (по данным Росстата в 2012-2016 годах). Международный журнал прикладных и фундаментальных исследований. 2018; (8): 49-53.

7. Щеголев А. И., Павлов К. А., Дубова Е. А., Фролова О. Г. Ранняя неонатальная смертность в Российской Федерации в 2010 г. Архив патологии. 2013; (4): 15-19.

8. Методические рекомендации по кодированию и выбору основного состояния в статистике заболеваемости и первоначальной причины в статистике смертности, связанных с COVID-19. 2020; 24 с. Доступно по ссылке: https://static-1. rosminzdrav.ru/system/attachments/attaches/000/050/527/ original/27052020_MR_STAT_1.pdf.

9. Schwartz DA. An analysis of 38 pregnant women With COVID-19, their newborn infants, and maternal-fetal transmission of SARSCoV-2: Maternal coronavirus infections and pregnancy outcomes. Arch Pathol Lab Med. 2020; 144 (7): 799-805.

10. Neef V, Buxmann H, Rabenau HF, Zacharowski K, Raimann FJ. Characterization of neonates born to mothers with SARS-CoV-2 infection: Review and meta-analysis. Pediatr Neonatol. 2021; 62 (1): 11-20.

11. WHO COVID-19 LENS (Living Evidence Synthesis) Working Group. Definition and categorization of the timing of motherto-child transmission of SARS-CoV-2. Available from: www. who.int/publications/i/item/WHO-2019-nCoV-mother-tochildtransmission-2021.1

12. Garcia-Basteiro AL, Moncunill G, Tortajada M, Vidal M, Guinovart C Jiménez A, et al. Seroprevalence of antibodies against SARSCoV-2 among health care workers in a large Spanish reference hospital. Nat Commun. 2020; 11 (1): 3500.

13. Sutton D, Fuchs K, D'Alton M, Goffman D. Universal screening for SARS-CoV-2 in women admitted for delivery. N Engl J Med. 2020; 382 (22): 2163-4.

14. Ferrazzi E, Frigerio L, Savasi V, Vergani P., Prefumo F, Barresi S, et al. Vaginal delivery in SARS-CoV-2-infected pregnant women in Northern Italy: A retrospective analysis. BJOG. 2020; 127 (9): 1116-21.

15. Vivanti AJ, Vauloup-Fellous C, Prevot S, Zupan V, Suffee C, Do Cao J, et al. Transplacental transmission of SARS-CoV-2 infection. Nat Commun. 2020; 11 (1): 3572.

16. Raschetti R, Vivanti AJ, Vauloup-Fellous C, Loi B, Benachi A, De Luca D. Synthesis and systematic review of reported neonatal SARS-CoV-2 infections. Nat Commun. 2020; 11 (1): 5164.

17. Shchegolev AI, Tumanova UN. Persistence of SARS-COV-2 in deceased patients and safe handling of infected bodies. Bulletin of RSMU. 2021; (3): 5-11.

18. Дегтяев Д. Н. Можно ли рассматривать вирус SARS-COV-2 в качестве возбудителя TORCH-инсекций у новорожденных? Неонатология: новости, мнения, обучение. 2021; (1): 5-7.

19. Li X, Sun L, Tao L. Updates in neonatal coronavirus disease 2019: What can we learn from detailed case reports? (Review). Mol Med Rep. 2021; 23 (5): 351.
20. Crovetto F, Crispi F, Llurba E, Pascal R, Larroya M, Trilla C, et al. Impact of SARS-CoV-2 infection on pregnancy outcomes: A population-based study. Clin Infect Dis. 2021: ciab104.

21. Yan J, Guo J, Fan C, Juan J, Yu X, Li J, et al. Coronavirus disease 2019 in pregnant women: a report based on 116 cases. Am J Obstet Gynecol. 2020; 223 (111): e1-14.

22. Knight M, Bunch K, Vousden N, Morris E, Simpson N, Gale C, et al. UK obstetric surveillance system SARSCoV-2 infection in Pregnancy Collaborative Group. Characteristics and outcomes of pregnant women admitted to hospital with confirmed SARSCoV-2 infection in UK: national population based cohort study. BMJ. 2020; 369: m2107.

23. Lee DH, Lee J, Kim E, Woo L, Park HY, An J. Emergency cesarean section performed in a patient with confirmed severe acute respiratory syndrome coronavirus-2 - a case report. Korean J Anesthesiol. 2020; 73 (4): 347-51.

24. Gracia-Perez-Bonfils A, Martinez-Perez O, Lurba E, Chandraharan E. Fetal heart rate changes on the cardiotocograph trace secondary to maternal COVID-19 infection. Eur J Obstet Gynecol Reprod Biol. 2020; 252: 286-93.

25. Oltean I, Tran J, Lawrence S, Ruschkowski BA, Zeng N, Bardwell C, et al. Impact of SARS-CoV-2 on the clinical outcomes and placental pathology of pregnant women and their infants: A systematic review. Heliyon. 2021; 7 (3): e06393.

26. Щеголев А. И., Туманова У. Н., Серов В. Н. Поражения плаценты у беременных с SARS-CoV-2-инфекцией. Акушерство и гинекология. 2020: (12): 44-52.

27. Щеголев А. И., Куликова Г. В., Туманова У. Н., Шмаков Р. Г., Сухих Г. Т. Морфометрическая характеристика ворсин плаценты рожениц с COVID-19. Бюллетень экспериментальной биологии и медицины. 2021; 172 (7): 102-7.

28. Shchegolev Al, Kulikova GV, Lyapin VM, Shmakov RG, Sukhikh GT. The number of syncytial knots and vegf expres-sion in placental villi in parturient woman with COVID-19 depends on the disease severity. Bull Exp Biol Med. 2021; 171 (3): 399-403.

29. Italian National Institute of Health. COVID-19: National Update 24 March 2021 (Italian Version). Available from: www.epicentro.iss.it/ coronavirus/bollettino/Bollettino-sorveglianza-integrata-COVID19 24-marzo-2021.pdf.

30. Juan J, Gil MM, Rong Z, Zhang Y, Yang H, Poon LC. Effect of coronavirus disease 2019 (COVID-19) on maternal, perinatal and neonatal outcome: systematic review. Ultrasound Obstet Gynecol. 2020; 56 (1): 15-27.

31. Bellos I, Pandita A, Panza R. Maternal and perinatal outcomes in pregnant women infected by SARS-CoV-2: A meta-analysis. Eur J Obstet Gynecol Reprod Biol. 2021; 256: 194-204.

32. Li J, Wang Y, Zeng Y, Song T, Pan X, Jia M, et al. Critically ill pregnant patient with COVID-19 and neonatal death within two hours of birth. Int J Gynaecol Obstet. 2020; 150 (1): 126-128.

33. Zhu $\mathrm{H}$, Wang $L$, Fang $C$, Peng $S$, Zhang $L$, Chang $G$, et al. Clinical analysis of 10 neonates born to mothers with 2019-nCoV pneumonia. Transl Pediatr. 2020; 9: 51-60.

34. WAPM (World Association of Perinatal Medicine) Working Group on COVID-19. Maternal and perinatal outcomes of pregnant women with SARS-CoV-2 infection. Ultrasound Obstet Gynecol. 2021; 57 (2): 232-41. 